\title{
Páginas de devoção e de sensação: gênero e história social do livro e da leitura*
}

\section{Heloisa Pontes ${ }^{* *}$}

Por uma dessas coincidências felizes, os livros da historiadora Leila Mezan Algranti e da antropóloga Alessandra EI Far foram editados no mesmo ano e lançados no mesmo mês, em novembro de 2004. Com todas as letras, ambos mostram a força da palavra impressa quando lida no registro, necessariamente interdisciplinar, da história social do livro. Do encontro entre a perspectiva historiográfica e antropológica, abre-se um universo fascinante de pesquisa e análise. Tomando os livros não apenas (o que está longe de ser pouco) pelo seu conteúdo substantivo, na linha praticada pela história das idéias, as autoras os usam como chaves preciosas para adentrar o imaginário e a sociabilidade de grupos sociais específicos. Em comum, perseguem pistas, sinais e rastros deixados pelos livros e sua circulação. Atentas às práticas de leitura e aos seus significados distintos em função do público a que se destinam, às convenções narrativas que informam tanto os gêneros interditos como os de maior visibilidade na época, às relações de gênero como marcadores relevantes na trama armada pelas interações sociais, as autoras iluminam, com novas luzes, aquilo que Robert Darnton chamou de "ciclo de vida dos livros". Isto é, o seu longo e complexo processo de produção, divulgação e consumo. Contribuindo, assim, para um entendimento mais

\footnotetext{
* Recebida para publicação em junho de 2005, aprovada em junho de 2005. Resenha dos livros de Algranti, Leila Mezan. Livros de devoção, atos de censura. Ensaios de história do livro e da leitura na América Portuguesa (17501821). São Paulo, Hucitec/Fapesp, 2004; e de EL FAR, Alessandra. Páginas de sensação: literatura popular e pornográfica no Rio de J aneiro (1870-1924). São Paulo, Companhia das Letras, 2004.

** Departamento de Antropologia/IFCH ; pesquisadora do Núcleo de Estudos de G ênero - Pagu, ambos da Unicamp.
} 
Páginas de devoção e de sensação

qualificado das implicações sociais e culturais do ato da leitura e de sua difusão.

$\mathrm{H}$ istoriadora experiente e analista atilada, Leila Algranti, em Livros de devoção, atos de censura. Ensaios de história do livro e da leitura na América Portuguesa (1750-1821), põe em conexão as práticas de leitura de mulheres enclausuradas em recolhimentos ou conventos e o sistema de censura que recaía sobre os livros e sua circulação na América Portuguesa. Não menos atilada, a jovem antropóloga Alessandra El Far, em Páginas de sensação: literatura popular e pornográfica no Rio de J aneiro (1870-1924), volta-se para o nascente e promissor mercado editorial brasileiro com o propósito de descortinar as razões do enorme sucesso dos chamados romances de "sensação" e dos livros "para homens".

Originalmente concebido como uma tese de livre-docência, - livro de Leila Algranti é composto de sete ensaios independentes, que, embora possam ser lidos em separado, ganham força renovada quando vistos em conjunto. Não só em virtude da unidade que apresentam - a busca por um entendimento mais circunstanciado do que se lia na América Portuguesa, quem lia o quê e como se liam os livros que circulavam na época - como por desdobrarem os temas comuns em novos arranjos analíticos. Para um leitor ou uma leitora não especializada na historiografia do período, esses desdobramentos soam como uma frase melódica que a cada aparição refaz de forma sintética o percurso anterior da melodia e delineia os temas seguintes. Advém daí um dos encantos desse trabalho vigoroso. Enredando o leitor na sua narrativa espiralar, faz dele uma espécie de cúmplice das descobertas da autora. Recurso deliberado ou involuntário, essa estratégia narrativa ancora-se, por sua vez, numa sólida pesquisa documental e no rigor analítico da historiadora, que dá continuidade nesse livro ao estudo das bibliotecas das casas de reclusão de mulheres leigas, chamadas de recolhimento, objeto de sua tese de doutorado. Mas se, em H onradas e devotas: mulheres da colônia, Leila estava interessada em examinar as descontinuidades entre o que se passava na 
metrópole e na colônia, neste livro buscou as semelhanças e continuidades, mais intensas que as rupturas, no âmbito da cultura religiosa em que as mulheres reclusas estavam imersas, tanto lá como aqui.

Livros de devoção e atos de censura são a face e contra-face de um mesmo universo social e cultural, assentado em um catolicismo barroco e no absolutismo português. Segmento dos livros religiosos, os de devoção englobam os livros de horas, os folhetos de orações, as obras místicas e as vidas de santos. As duas últimas, de grande popularidade na época, marcaram presença nas bibliotecas dos recolhimentos e dos conventos localizados na América Portuguesa. Um dos poucos espaços de leitura disponível para as mulheres, destinados à preservação da honra feminina, ao acolhimento de órfãs pobres ou da nobreza, e, em alguns casos, de mulheres que desafiavam os códigos de conduta e de moralidade do período, era ali também que elas liam, em voz alta ou em silêncio, no caso das mais letradas e não por acaso mulheres de elite, as obras místicas e as vidas de santos. Leitoras disciplinadas e fervorosas, essas mulheres fizerem um uso singular desses livros. Tomaram-nos como modelo narrativo para escreverem autobiografias ou as biografias daquelas que mais se destacaram entre elas, com a finalidade de enaltecer também os recolhimentos que as acolheram, no caso das leigas, ou os conventos a que pertenceram, no caso das religiosas professas. Modelos de escrita que serviam para potencializar modelos de virtude, calcados na vivência de uma religiosidade funda, os livros de devoção são produtos de uma dupla convenção: narrativa e moral. É esta convenção que confirma e conforma as vidas virtuosas dessas mulheres que foram mais que consumidoras passivas das obras que liam. Confinadas nesses espaços exclusivamente femininos, elas usaram a leitura e a escrita como meios para discorrer sobre suas missões na terra, a união com Deus, o significado de suas vidas, expressando, assim, uma subjetividade que não se separava da afirmação, ainda que enviesada, de um poder político rarefeito. Neste compasso, 
Páginas de devoção e de sensação

desenharam uma escrita própria (feminina?), a única possível no interior da Igreja que, dando aos homens o direito de falar nos sermões e na confissão e de se pronunciarem por escrito nos estatutos, regulamentos e nas obras de teologia, negava-o às mulheres.

Conjugando, no plano analítico, as convenções do gênero literário que presidiam a escrita da vida dos santos, às convenções de gênero que modelavam as relações sociais da época, Leila Algranti escrutinou a biblioteca e a vida interessantíssima da mística J acinta de São J osé. Fundadora do convento de Santa Tereza no Rio de Janeiro, ela foi denunciada à Inquisição de Lisboa como falsária, em 1753 pelo bispo da cidade, Dom Antonio de Desterro. Revirando pelo avesso a documentação disponível sobre ela e sobre o imbróglio em que se metera (aqui e em Portugal), mas do qual sairia vitoriosa, Leila a transforma na personagem paradigmática do livro. Jacinta era leitora da obra mística de Santa Tereza e nutria por ela uma devoção a tal ponto intensa, que não apenas "via" e "conversava" com a santa, como tinha visões semelhantes às dela. Espelhando-se nela, ou melhor, no que lera sobre ela, tomou-a como modelo para guiar a si própria nos assuntos terrestres e principalmente nos de ordem divina. À luz dos trabalhos de Raymond Williams, diríamos que a leitura das vidas de santo fornecia a "estrutura dos sentimentos" que modelava não apenas a narrativa como a biografia dessas mulheres reclusas.

A vida e a biblioteca de Jacinta ampliam os temas analisados pela historiadora, permitindo-nos um entendimento mais nuançado da experiência tortuosa da religiosidade barroca e de seu entrelaçamento aos livros lidos. Mas se a literatura de cunho religioso marcou a vida dessas mulheres e o século em que viveram, com o passar do tempo e conforme avançava o processo de laicização da sociedade portuguesa e, por extensão, de sua principal colônia, ela foi perdendo força. A censura aos livros e a sua circulação, porém, no lugar de arrefecer só aumentou com a transferência da corte portuguesa para o Rio de J aneiro, em 1808. 
Duplamente censurados - primeiro em Portugal onde eram editados, em seguida no Rio de Janeiro, ao desembarcarem nas malas de comerciantes ou viajantes - os livros passavam pelo crivo da Real Mesa Censória e depois pela Mesa do Desembargo do Paço, órgão censor de D. J oão VI.

Censura régia e eclesiástica, exercida por um corpo qualificado de funcionários - leitores vorazes, em sua maioria, tendentes a concordar quando se tratava de censurar obras que atentassem contra a religião ou a política absolutista, mas menos consensuais sobre aquelas que incidiam sobre a moral - ela fornece à historiadora o enlace necessário para articular a prática da leitura ao domínio da circulação dos livros. Seletiva e discricionária, como tudo no Antigo Regime - onde os homens e as mulheres da aristocracia e da nobreza se viam como pessoas melhores e definitivamente não se pensavam como iguais aos outros, os "inferiores" - a censura é devassada em seus bastidores por Leila Algranti. Tanto pela análise do perfil social, intelectual e político dos funcionários encarregados de exercê-la aqui, os chamados "homens bons", como pelo exame da lista de livros que chegavam à cidade de navio. Como nenhum material impresso podia circular sem antes passar pelo olhar vigilante desses censores, Leila encontra nessa fonte o elo que faltava para vislumbrar as modificações mais importantes no perfil das obras lidas pelos habitantes da América Portuguesa.

Com a independência e à medida que transcorria o século $X I X$, aquilo que a historiadora constatou em termos da importância crescente do romance, das obras de ciências, dos relatos de viagens e do visível retraimento dos livros religiosos, entre eles os de devoção, torna-se 0 assunto central da antropóloga Alessandra EI Far. Não só em virtude da continuidade cronológica, mas, sobretudo, pela maneira como ela descortina a formação de um mercado editorial entre nós atrelado à produção e ao consumo de dois dos seus gêneros mais populares: os chamados "romances de sensação" e os livros "para homens". Estórias mirabolantes, repletas de mistérios, crimes, 
Páginas de devoção e de sensação

sangue, amores desencontrados, desejos irrealizados ou irrealizáveis davam o tom dos primeiros e "brotavam como cogumelos" nas edições da época. Ao lado delas, as publicações explicitamente destinadas aos homens, os tais dos livros que se lêem com uma só mão, que abusavam das cenas de sexo. Os ambientes e as personagens eram os mais diversos, de frades priápicos a freiras libidinosas, passando por mulheres sôfregas e por libertinos prontos a romper todas as regras. Mas o objetivo do enredo era sempre o mesmo: ampliar os estados de excitação que, consumados nos textos e nos corpos dos leitores, davam origem a rápidos períodos de calmaria imprescindíveis para a preparação do gozo que viria a seguir. Nesse compasso de espera por cenas de luxúria, valia tudo, inclusive a abolição temporária de diferenças sociais e de relações de poder.

Enquanto no trabalho de Leila, devoção e mulheres formam uma equação, no de Alessandra, pornografia e homens apelam-se mutuamente. Não por características intrínsecas aos gêneros. $E$ sim por sua orquestração social e cultural. Se a biblioteca de Jacinta constitui a fonte privilegiada por Leila para acessar 0 universo de suas leitoras, a de Alessandra são os próprios livros. Taxados de pornográficos na época, eles, ao contrário das obras de devoção, não são fáceis de localizar nos acervos das bibliotecas públicas. E, por isto, foram sendo encontrados a esmo, graças à pesquisa obstinada da autora, aqui e em Portugal. Para interpretar os sentidos e os significados que os livros de "sensação" voltados tanto para as mulheres como para os homens, lidos talvez mais por eles que por eles - e os de cunho pornográfico poderiam ter para os leitores do oitocentos, a antropóloga faz, de um lado, uma análise do conteúdo dos textos. De outro lado, refaz o contexto mais amplo da sociedade brasileira entre os anos de 1870 e 1920, com o propósito de destacar os valores e os conflitos que recobriam o plano da moralidade e a maneira como eles foram apropriados pelos leitores, pelas editoras e pelos editores empenhados na divulgação das obras em foco. Os últimos, como sabido, não mediram esforços para alardear 0 alcance popular de 
seus produtos, valendo-se inclusive de uma prática corrente no meio: adulterar o número de edições com a finalidade de dar aos livros uma visibilidade e repercussão maiores do que de fato tiveram. Números exagerados conviviam bem com essas narrativas mirabolantes, plenas de "sensação" ou de pornografia.

Com um texto ágil e bem torneado, Alessandra duplica o efeito do seu objeto. Páginas de sensação são a um só tempo os livros sob seu escrutínio e o resultado de sua narrativa. Se este é um dos grandes méritos do seu trabalho é também o lugar onde algumas arestas de ordem metodológica teimam em aparecer. Por não dispor de uma fonte tão rica para a reconstituição do universo dos leitores, como as bibliotecas examinadas por Leila, ou de dados confiáveis sobre a recepção, Alessandra ateve-se quase que exclusivamente ao conteúdo narrativo das obras, para ousar uma interpretação possível sobre os sentidos e os significados que elas teriam para os seus leitores. 0 problema espinhoso das mediações analíticas necessárias para "ler" o que se "lia" em épocas distintas da nossa - ou até mesmo na nossa, quando a leitura é feita por grupos sociais a que não pertencemos - é enfrentado por ela com 0 arsenal conceitual fornecido pela antropologia interpretativa e por intermédio da reconstituição dos grandes painéis e contextos de época. E ainda que a autora, na conclusão do seu trabalho, reitere a importância das convenções literárias e narrativas que presidiam a feitura das obras examinadas - o melodrama e a pornografia libertina do antigo regime - elas teriam ajudado, e muito, se exploradas no decorrer do trabalho, a dar mais fôlego ao esforço interpretativo da autora. Pois se é certo que essas publicações "dialogavam com os padrões sociais e culturais da época, colocando em pauta as expectativas, temores e ansiedades de uma parcela representativa da sociedade carioca" (p.310), é certo também que esse "diálogo" foi filtrado pelas convenções dos gêneros literários em tela. São elas que tornam possível burlar a moralidade autorizada e as expectativas concernentes à dinâmica das relações sociais, suspendendo-as temporariamente até que encerrada a leitura, todos voltem aos seus lugares devidos: os 
Páginas de devoção e de sensação

homens e as mulheres, os jovens e os adultos, os pobres e os ricos.

Não quero com essa ponderação negar a dimensão subversiva contida nos livros - disso dão testemunho os tais dos "homens bons" analisados por Leila Algranti. Zelosos em impedir a proliferação do romance no início dos Oitocentos, pelos malefícios que esse gênero literário poderia causar em criaturas tão "frágeis" e "sugestionáveis" como as mulheres, esses funcionários eram taxativos quando se tratava de censurar obras de cunho pornográfico. Se com o fim do sistema de censura, essas obras puderam circular mais livremente, não deixaram, contudo, de visar um público específico, majoritariamente masculino, como mostra Alessandra. E mesmo que as mulheres pudessem lê-las às escondidas e também com uma só mão, poucos são os indícios disponíveis para cercar essa suposição com evidências mais sólidas. Nesse ir e vir do texto ao contexto interpõem-se os problemas da recepção e das convenções. Impossibilitada pela ausência de fontes seguras de enfrentar o primeiro, a autora passou de raspão pelo segundo.

Reparo à parte, o livro de Alessandra é um belo exemplo do quanto a antropologia tem a contribuir para o adensamento da história social do livro. Sua leitura em conjunto com o primoroso trabalho da historiadora Leila Algranti mostra o vigor desse cruzamento interdisciplinar, sobretudo quando atento às pistas e às marcas deixadas pelas relações de gênero. 